\title{
MENGATASI KESULITAN MAHASISWA TENTANG MATERI PERSAMAAN DIFERENSIAL MENGGUNAKAN BIMBINGAN BELAJAR INDIVIDUAL (FACE TO FACE RELATIONSHIP) BERBANTUAN PROGRAM MAPLE
}

\author{
Beni Asyhar ${ }^{1}$ dan Dewi Asmarani² \\ ${ }^{1,2}$ Jurusan Tadris Matematika Fakultas Tarbiyah dan Ilmu Keguruan \\ Institut Agama Islam Negeri (IAIN) Tulungagung \\ e-mail: dewi_asmarani.iainta@yahoo.com ${ }^{1}$, asyhar_beni@yahoo.com ${ }^{2}$
}

\begin{abstract}
Abstrak
Penelitian ini bertujuan untuk mengatasi kesulitan mahasiswa dalam memahami tentang materi Persamaan Diferensial menggunakan bimbingan belajar individual (face to face relationship) berbantuan program Maple. Penelitian ini merupakan jenis Penelitian Tindakan Kelas (PTK). Subyek penelitiannya mahasiswa S-1 Jurusan Tadris Matematika IAIN Tulungagung semester VI (enam) kelas E tahun akademik 2014/2015. Hasil penelitian ini adalah: 1) Pembelajaran dengan menggunakan bimbingan belajar individual (face to face relationship) berbantuan program Maple terdiri dari tiga tahap, yaitu: (i) tahap awal meliputi penyampaian tujuan pembelajaran, memeriksa pengetahuan prasyarat, mengatur tempat duduk, dan membagikan LKM, (ii) tahap inti meliputi proses bimbingan individual berbantuan media komputer berupa program Maple dan LKM, (iii) tahap akhir meliputi penarikan kesimpulan hasil pembelajaran dan melakukan evaluasi. 2) Pembelajaran dengan menggunakan bimbingan belajar individual (face to face relationship) berbantuan program Maple dapat mengatasi kesulitan mahasiswa dalam memahami materi dan prosedur penyelesaian Persamaan Diferensial (PD), dan 3) respon mahasiswa terhadap pembelajaran tentang PD Persamaan Diferensial (PD) menggunakan bimbingan belajar individual (face to face relationship) berbantuan program Maple dalam penelitian ini adalah positif.
\end{abstract}

Kata Kunci: Kesulitan, Persamaan Diferensial, Bimbingan Individual, Maple

\section{PENDAHULUAN}

Persamaan Diferensial (PD) merupakan salah satu mata kuliah yang dipelajari oleh mahasiswa Strata 1 (S1) Matematika maupun Pendidikan Matematika. Suatu bentuk persamaan yang memuat turunan (derivatif) satu atau lebih variabel tak bebas terhadap satu atau lebih variabel bebas suatu fungsi disebut Persamaan Diferensial (PD). Pada saat menempuh mata kuliah tersebut, mayoritas mahasiswa mengalami kesulitan dalam memahami konsep maupun menentukan penyelesaiannya, terutama pada saat dihadapkan dengan materi prasyarat, yaitu konsep turunan (derivatif) dan integral. Mahasiswa cenderung 
lupa terhadap materi prasyarat dan cara menyelesaikannya. Selain itu, mahasiswa yang kesulitan cenderung kurang mendapat perhatian. Oleh karena itu, diperlukan usaha yang serius dalam mengatasi kesulitan tersebut. Salah satu cara yang dapat digunakan untuk mengatasi kesulitan mahasiswa adalah dengan mengadakan bimbingan individual berbantuan program Maple.

Bimbingan atau konseling merupakan hubungan pribadi yang dilakukan secara tatap muka antara dua orang di mana konselor melalui hubungan itu dengan kemampuan khusus yang dimilikinya menyediakan situasi belajar untuk membantu klien memahami diri sendiri, keadaannya sekarang, dan kemungkinan keadaan masa depan yang dapat diciptakan dengan menggunakan potensi yang dimilikinya, demi untuk kesejahteraan pribadi maupun masyarakat. Selanjutnya, bimbingan belajar individual (face to face relationship) atau secara umum dapat diartikan sebagai hubungan empat mata merupakan pertemuan antara konselor dengan klien secara individu, di mana terjadi hubungan konseling yang bernuansa repport, dan konselor berupaya memberikan bantuan untuk pengembangan pribadi klien serta klien dapat mengantisipasi masalah-masalah yang dihadapinya. Metode ini digunakan dalam pelaksanaan pembelajaran di kelas dengan cara pendidik (konselor) memberikan bimbingan kepada klien (mahasiswa) secara individu. Pendidik, dalam hal ini bertindak sebagai konselor berusaha mengarahkan klien (mahasiswa) sesuai dengan kesulitan-kesulitan yang dihadapi dalam pembelajaran, memberikan saran, dan nasehat serta motivasi kepada klien (mahasiswa).

Penggunaan metode pembelajaran bimbingan belajar individual (face to face relationship) diharapkan dapat menjangkau semua kesulitan masing-masing mahasiswa terkait dengan materi prasyarat maupun materi Persamaan Diferensial. Dengan metode pembelajaran ini, semua mahasiswa dapat bertanya dan meminta bantuan kepada dosen terkait dengan masalah pembelajaran, baik masalah materi prasyarat maupun materi Persamaan Diferensial. Selain itu, mahasiswa juga dapat meminta saran, petunjuk, atau nasihat yang berkaitan dengan pembelajaran secara umum dan secara khusus mengenai mata kuliah Persamaan Diferensial. Selain itu, konselor (dosen) dapat mengetahui kesulitan masing-masing mahasiswa dalam memahami Persamaan Diferensial secara langsung atau secara bertatap muka, baik kesulitan yang berkaitan dengan materi prasyarat maupun materi tentang Persamaan Diferensial. Oleh karena itu, dosen akan secara langsung memberikan bantuan terkait dengan masalah tersebut dan juga dosen dapat memberikan saran, petunjuk, atau nasihat untuk kemajuan masing-masing mahasiswa.

Berkaitan dengan metode pembelajaran bimbingan belajar individual (face to face relationship), penggunaan metode ini berbantuan program Maple akan dapat membantu kesulitan mahasiswa dalam mempelajari materi Persamaan Diferensial. Maple merupakan software atau paket aplikasi matematika yang dapat digunakan untuk melakukan berbagai perhitungan matermatis baik secara eksak (analitik) maupun numerik. Dengan kemampuan yang dimiliki, Maple merupakan suatu alat bantu yang handal untuk pemecahan masalah matematika, baik masalah komputasi numerik, aljabar simbolik, maupun visualisasi (grafik). 
Perpaduan antara penggunaan metode pembelajaran bimbingan belajar individual (face to face relationship) dan program Maple akan memudahkan mahasiswa dalam menyelesaikan Persamaan Diferensial secara komputasi. Penggunaan program Maple akan membantu mahasiswa dalam mengecek kebenaran penyelesaian secara manual (analitik). Oleh karena itu, kesulitan-kesulitan mahasiswa dalam memahami tentang materi prasyarat atau materi Persamaan Diferensial dapat diatasi menggunakan bimbingan belajar individual (face to face relationship) berbantuan program Maple.

\section{METODE}

Penelitian ini merupakan jenis Penelitian Tindakan Kelas (PTK) karena kegiatan dalam penelitian ini adalah bertujuan untuk mengatasi kesulitan mahasiswa dalam memahami materi Persamaan Diferensial dengan menggunakan rencana tindakan bersiklus yang melibatkan inkuiri pada saat mahasiswa berdiskusi atau memperoleh bimbingan secara individu mulai dari menggunakan teorema atau sifat turunan (derivatif) dan integral sampai menyelesaikan Lembar Kerja Mahasiswa (LKM) atau termasuk dalam pengumpulan informasi, analisis, dan refleksi. Subyek penelitian ini adalah mahasiswa S-1 Jurusan Tadris Matematika IAIN Tulungagung semester VI (enam) kelas E tahun akademik 2014/2015 sebanyak 20 orang.

Data yang akan dikumpulkan dalam penelitian ini meliputi: 1) hasil tes mahasiswa dalam mengerjakan soal-soal tes awal tentang turunan (derivatif) dan integral, 2) hasil tes mahasiswa dalam mengerjakan soal-soal tes akhir tentang Persamaan Diferensial, 3) hasil pengamatan aktivitas peneliti dan mahasiswa selama kegiatan pembelajaran tentang penggunaan bimbingan belajar individual (face to face relationship) berbantuan program Maple untuk mengatasi kesulitan mahasiswa dalam memahami tentang materi prasyarat atau materi Persamaan Diferensial, 4) hasil kajian dan wawancara tentang pekerjaan mahasiswa, dan 5) catatan lapangan tentang kejadian atau peristiwa yang tidak terduga munculnya.

Instrumen penelitian dalam penelitian ini adalah: 1) RPP, 2) LKM, 3) Lembar Tes, 4) pedoman pengamatan, dan 5) pedoman wawancara. Sedangkan pengumpulan datanya menggunakan tes, pengamatan, wawancara, dan catatan lapangan. Data yang dianalisis dalam penelitian ini adalah data tentang hasil tes belajar dan aktivitas peneliti dan mahasiswa selama pembelajaran berlangsung.

\section{PEMBAHASAN}

\section{A. Pembelajaran Persamaan Diferensial (PD) Menggunakan Bimbingan Belajar Individual (Face to Face Relationship) Berbantuan Program Maple}

Pengenalan konsep Persamaan Diferensial (PD) dan prosedur penyelesaiannya dimulai dengan penyampaian tujuan pembelajaran oleh peneliti. Pada saat pelaksanaan penelitian ini, mahasiswa tampak sangat antusias memperhatikan penjelasan tujuan pembelajaran yang disampaikan oleh peneliti. Hal ini sesuai pendapat Dahar yang 
mengatakan bahwa dengan adanya penyampaian tujuan pembelajaran peserta didik dapat termotivasi dan dapat memusatkan perhatiannya terhadap materi yang disampaikan.

Pembelajaran konsep PD dan prosedur penyelesaiannya dilakukan dengan menggunakan LKM. Penggunaan LKM terbukti sangat membantu arah kerja atau belajar mahasiswa. Hal ini karena Lembar Kerja memang berfungsi sebagai penuntun belajar peserta didik. $^{\dagger}$ Langkah-langkah yang ditentukan dalam LKM merupakan suatu bentuk bantuan bagi mahasiswa. Meskipun demikian, LKM tidak menuntun mahasiswa secara mutlak. LKM hanya menguraikan langkah-langkah secara garis besar. Mahasiswa masih diberikan kebebasan untuk mengungkapkan ide dan kreativitasnya. Dengan demikian, mahasiswa membentuk pengetahuan mereka sendiri dengan bantuan LKM. Pada saat membaca LKM, peneliti memberikan bimbingan individual kepada semua mahasiswa yang mengalami kesulitan memahami materi maupun prosedur penyelesaian PD secara bergiliran.

Selain menggunakan LKM, dalam pembelajaran konsep konsep PD dan prosedur penyelesaiannya juga digunakan media pembelajaran berupa program Maple, yaitu software atau paket aplikasi matematika yang dapat digunakan untuk melakukan berbagai perhitungan matematis baik secara eksak (analitik) maupun numerik. Dengan kemampuan yang dimiliki, Maple merupakan suatu alat bantu yang handal untuk pemecahan masalah matematika, baik masalah komputasi numerik, aljabar simbolik, maupun visualisasi (grafik). Penggunaan program Maple terbukti membantu mahasiswa memahami dan menentukan penyelesaian PD. Dengan adanya soal latihan yang disajikan dalam bentuk penyelesaian analitik dan menggunakan program Maple dapat mengatasi kesulitan mahasiswa dan menambah pemahaman mahasiswa secara lebih baik.

Bimbingan individual dalam penelitian ini memberikan banyak keuntungan bagi mahasiswa. Mahasiswa dapat berdiskusi secara intensif dengan peneliti mengenai kesulitan yang dihadapi. Mahasiswa bertanya langsung kepada peneliti mengenai hal-hal yang belum dipahami. Sedangkan peneliti memberikan bimbingan secara individual kepada semua mahasiswa yang mengalami kesulitan memahami materi maupun penyelesaian PD. Hal ini sesuai dengan tujuan adanya konseling atau bimbingan individu, yaitu untuk mengentaskan masalah yang dialami klien (mahasiswa). ${ }^{\ddagger}$

Setelah bimbingan individual selesai, peneliti berdiskusi dengan semua mahasiswa terkait dengan materi yang dipelajari. Selanjutnya peneliti mengadakan evaluasi terhadap pembelajaran yang berlangsung melalui tanya jawab secara lisan untuk mengecek kembali pemahaman mahasiswa. Peneliti perlu memastikan bahwa semua mahasiswa dapat memahami materi yang baru dipelajari. Sebagai penutup, atas arahan dan bimbingan peneliti

\footnotetext{
* Ratna Wilis Dahar, Teori-teori Belajar, (Jakarta: Dedikbud P2LPTK, 1988), hal. 174

$\dagger$ Andi Prastowo, Panduan Kreatif Membuat Bahan Ajar Inovatif: Menciptakan Metode Pembelajaran yang Menarik dan Menyenangkan, (Yogyakarta: Diva Press, 2011), hal. 208

* Tohari, Bimbingan dan Konseling ..., hal. 164
} 
mahasiswa membuat kesimpulan akhir pembelajaran. Hal ini sesuai pendapat Degeng yang mengatakan bahwa membuat kesimpulan atau rangkuman terhadap apa yang telah dipelajari perlu dilakukan untuk mempertahankan retensi. ${ }^{\S}$

\section{B. Hasil Belajar Mahasiswa Tentang Konsep Persamaan Diferensial (PD) Menggunakan Bimbingan Belajar Individual (Face to Face Relationship) Berbantuan Program Maple}

Pembelajaran dengan menggunakan bimbingan belajar individual (face to face relationship) berbantuan program maple dalam penelitian ini bertujuan untuk mengatasi kesulitan mahasiswa dalam memahami konsep dan prosedur penyelesaian PD. Materi pembelajaran siklus I adalah: 1) Persamaan Diferensial (PD) dan dapat mengetahui prosedur penyelesaian PD, 2) PD Terpisah dan dapat mengetahui prosedur penyelesaian PD Terpisah, dan 3) PD Homogen dan dapat mengetahui prosedur penyelesaian PD Homogen. Pada hasil tes akhir siklus I masih ada 8 atau $40 \%$ mahasiswa yang masih salah menjawab soal tes akhir, artinya masih banyak mahasiswa yang mengalami kesulitan. Mahasiswa yang memperoleh skor $\geq 61$ sebanyak 12 orang atau $60 \%$. Artinya, syarat skor minimal kelulusan yang ditentukan belum terpenuhi. Pada kriteria proses, aktivitas peneliti berada pada kategori baik untuk pertemuan II dan sangat baik untuk pertemuan I dan III. Sedangkan aktivitas mahasiswa berada pada kategori sangat baik untuk pertemuan I dan sangat baik untuk pertemuan II dan III. Dengan demikian, tindakan siklus I belum mencapai kriteria keberhasilan, baik dari segi proses maupun hasil. Kegiatan pembelajaran dilanjutkan dengan tindakan siklus II.

Materi pembelajaran pada siklus II adalah: 1) Persamaan Diferensial (PD) dengan Koefisien Linier dan dapat mengetahui prosedur penyelesaiannya, 2) PD Eksak dan dapat mengetahui prosedur penyelesaiannya, dan 3) PD Tak Eksak dan dapat mengetahui prosedur penyelesaiannya. Pada hasil tes akhir siklus II, ada 3 atau 15\% mahasiswa yang masih salah menjawab soal tes akhir. Kesalahan tersebut terletak pada kesalahan konsep dalam menjawab soal nomor 1 dan tidak teliti dalam menjawab soal nomor 2. Mahasiswa yang memperoleh skor $\geq 61$ sebanyak 19 orang atau 95\%. Artinya, syarat skor minimal kelulusan yang ditentukan sudah terpenuhi. Pada kriteria proses, aktivitas peneliti berada pada kategori sangat baik untuk semua pertemuan. Sedangkan aktivitas mahasiswa berada pada kategori sangat baik untuk pertemuan VI dan kategori baik untuk pertemuan IV dan V. Dengan demikian, tindakan siklus II telah mencapai kriteria keberhasilan, baik dari segi proses maupun hasil.

Pembelajaran PD menggunakan bimbingan belajar individual (face to face relationship) berbantuan program Maple untuk mengatasi kesulitan mahasiswa sudah dapat disimpulkan berhasil. Akan tetapi ada beberapa temuan penelitian yang perlu diperbaiki untuk lebih menyempurnakan hasil penelitian ini.

$\S$ I Nyoman Degeng, Strategi Pembelajaran Mengorganisasikan Isi dengan Elaborasi, (Malang: IKIP Malang, 1997), hal. 28 


\section{Alokasi Waktu}

Berdasarkan hasil pelaksanaan penelitian, peneliti menyimpulkan bahwa penggunaan bimbingan belajar individual (face to face relationship) berbantuan program Maple dalam pembelajaran PD memerlukan alokasi waktu yang cukup lama. Pada saat pelaksanaan, proses bimbingan individual terhadap mahasiswa yang kesulitan cenderung lama. Kesulitan mahasiswa bermacam-macam, mulai dari kesulitan memahami konsep sampai prosedur penyelesaian PD, bahkan ada mahasiswa yang minta didampingi sampai menemukan jawaban.

\section{Kemampuan Membuat Kesimpulan}

Variasi kesimpulan pada hasil LKM berhubungan dengan perbedaan penyelesaian langkah kerja yang dilakukan oleh masing-masing mahasiswa, tingkat ketelitian, dan pemahaman dalam mengerjakan LKM. Seorang mahasiswa dapat membuat kesimpulan dimulai dengan mempertimbangkan suatu hal khusus, mengorganisasikan hal khusus tersebut, dan mencari suatu pola yang kemudian dapat menuntun mahasiswa membuat kesimpulan.

Berdasarkan hasil pengamatan dan analisis terhadap hasil LKM, dapat dikatakan bahwa sebagian mahasiswa masih lemah dalam bernalar secara induktif. Mereka masih belum dapat melihat keteraturan pola yang terdapat pada langkah-langkah kerja yang dilakukannya dan menggeneralisasikan keteraturan pola tersebut.

\section{Respon Mahasiswa Terhadap Pembelajaran Persamaan Diferensial (PD) Menggunakan Bimbingan Belajar Individual (Face to Face Relationship) \\ Berbantuan Program Maple}

Respon mahasiswa terhadap pembelajaran tentang PD Persamaan Diferensial (PD) menggunakan bimbingan belajar individual (face to face relationship) berbantuan program Maple dalam penelitian ini adalah positif. Hal ini terlihat dari hasil wawancara terhadap subyek wawancara yang menyatakan senang, bersemangat, dapat membantu kesulitan mahasiswa, dan dapat meningkatkan pemahaman terhadap konsep PD. Begitu pula pada catatan lapangan oleh pengamat yang menyimpulkan bahwa pembelajaran tentang konsep PD menggunakan bimbingan belajar individual (face to face relationship) berbantuan program Maple dapat membuat mahasiswa aktif dalam bertanya dan menyampaikan kesulitankesulitan yang dihadapi tanpa merasa malu, sehingga kesulitan yang dihadapi segera dapat diselesaikan.

Selanjutnya, mahasiswa juga terlihat senang pada saat telah berhasil menyelesaikan PD yang diberikan secara analitik maupun menggunakan program Maple. Mereka terlihat serius dalam mengerjakan soal latihan PD secara analitik yang kemudian melakukan validasi menggunakan program Maple. Oleh karena itu, dengan menggunakan media komputer, yaitu software atau paket aplikasi matematika yang dan dikolaborasi dengan bimbingan belajar individual, maka kesulitan-kesulitan mahasiswa terkait materi Persamaan Diferensial dapat 
terselesaikan dan menarik perhatian mahasiswa. Hal ini sesuai dengan pendapat Hudojo, bahwa penggunaan media dalam pembelajaran akan lebih menarik perhatian peserta didik.**

\section{SIMPULAN DAN SARAN}

Berdasarkan paparan data hasil penelitian dan pembahasan, dapat disimpulkan beberapa hal berikut. 1) Pembelajaran dengan menggunakan bimbingan belajar individual (face to face relationship) berbantuan program Maple dapat mengatasi kesulitan mahasiswa dalam memahami materi dan prosedur penyelesaian Persamaan Diferensial (PD). Pembelajaran ini terdiri dari tiga tahap, yaitu: tahap awal, tahap inti, dan tahap akhir. Pada tahap awal, kegiatan yang dilakukan adalah menyampaikan tujuan pembelajaran, memeriksa pengetahuan prasyarat, mengatur tempat duduk, dan membagikan LKM. Pada tahap inti, kegiatan yang dilakukan adalah proses bimbingan individual untuk mempelajari konsep PD dan prosedur penyelesaiannya. Proses bimbingan ini dibantu dengan media komputer berupa program Maple dan LKM. Kemudian diakhiri diskusi dengan peneliti tentang materi yang dipelajari. Selanjutnya tahap akhir. Kegiatan pada tahap akhir adalah menyimpulkan hasil pembelajaran dan melakukan evaluasi secara lisan melalui tanya jawab. 2) Hasil belajar siklus I masih belum berhasil karena kriteria keberhasilannya belum tercapai. Pada hasil tes akhir siklus I masih ada 8 atau $40 \%$ mahasiswa yang masih salah menjawab soal tes akhir. Mahasiswa yang memperoleh skor $\geq 61$ sebanyak 12 orang atau 60\%. Artinya, syarat skor minimal kelulusan yang ditentukan belum terpenuhi. Aktivitas peneliti berada pada kategori baik untuk pertemuan II dan sangat baik untuk pertemuan I dan III dan aktivitas mahasiswa berada pada kategori sangat baik untuk pertemuan I dan sangat baik untuk pertemuan II dan III. Sedangkan pada hasil tes akhir siklus II, ada 3 atau 15\% mahasiswa yang masih salah menjawab soal tes akhir, baik salah konsep, prosedur, maupun tidak teliti. Mahasiswa yang memperoleh skor $\geq 61$ sebanyak 19 orang atau 95\%. Aktivitas peneliti berada pada kategori sangat baik untuk semua pertemuan dan aktivitas mahasiswa berada pada kategori sangat baik untuk pertemuan VI dan kategori baik untuk pertemuan IV dan V. Dengan demikian, tindakan siklus II telah mencapai kriteria keberhasilan, baik dari segi proses maupun hasil. 3) Respon mahasiswa terhadap pembelajaran tentang PD Persamaan Diferensial (PD) menggunakan bimbingan belajar individual (face to face relationship) berbantuan program Maple dalam penelitian ini adalah positif. Hal ini terlihat dari hasil wawancara terhadap subyek wawancara yang menyatakan senang, bersemangat, dapat membantu kesulitan mahasiswa, dan dapat meningkatkan pemahaman terhadap konsep PD.

Berdasarkan hasil penelitian ini dapat diberikan saran sebagai berikut: 1) Bagi dosen yang ingin menerapkan pembelajaran menggunakan bimbingan belajar individual (face to face relationship) berbantuan program maple untuk pembelajaran materi PD, hendaknya menyiapkan LKM yang dilengkapi dengan soal latihan beserta penyelesaiannya dan agar alokasi waktu yang disediakan cukup. Selain itu, hendaknya menyusun LKM yang bersisi langkah-langkah kerja yang mengarahkan mahasiswa untuk membuat kesimpulan yang

\footnotetext{
${ }^{* * *}$ Herman Hudojo, Mengajar Belajar Matematika, (Jakarta: Depdikbud, 1988), hal. 7
} 
benar. 2) Dosen hendaknya memperhatikan mahasiswa yang mengalami kesulitan dengan cara menciptakan suasana yang akrab antara peneliti dengan mahasiswa. Hal ini bertujuan agar proses pembelajaran berjalan dengan lancar dan mahasiswa tidak segan untuk bertanya atau berpartisipasi dalam proses pembelajaran.

\section{DAFTAR RUJUKAN}

Dahar, R. W. 1988. Teori-teori Belajar. Jakarta: Dedikbud P2LPTK.

Degeng, I. N. 1997. Strategi Pembelajaran Mengorganisasikan Isi dengan Elaborasi. Malang: IKIP Malang.

Hudojo, H. 1988. Mengajar Belajar Matematika. Jakarta: Depdikbud.

Prastowo, A. 2011. Panduan Kreatif Membuat Bahan Ajar Inovatif: Menciptakan Metode Pembelajaran yang Menarik dan Menyenangkan. Yogyakarta: Diva Press.

Prayitno \& Erman Amti. 2004. Dasar-dasar Bimbingan dan Konseling. Yogyakarta: PT. Rineka Cipta.

Tohari. 2009. Bimbingan dan Konseling di Sekolah dan Madrasah Berbasis Integrasi. Jakarta: PT. Raja Grafindo Persada.

Willis, S. S. 2010. Konseling Individual Teori dan Praktek. Bandung: Alfabeta. 